\title{
T Cells Reactive to a Single Immunodominant Self-restricted Allopeptide Induce Skin Graft Rejection in Mice
}

\author{
Anna Valujskikh, ${ }^{\star}$ Damir Matesic, ${ }^{*}$ Anita Gilliam, ${ }^{\ddagger}$ Donald Anthony, ${ }^{\S}$ Tarriq M. Haqqi, ${ }^{\S}$ and Peter S. Heeger ${ }^{\star \S \|}$ \\ *Department of Medicine, Cleveland Veterans Affairs Medical Center; and ${ }^{\ddagger}$ Department of Dermatology, ${ }^{\S}$ Department of Medicine, and

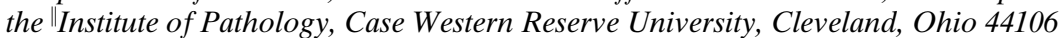

\begin{abstract}
Alloreactive $\mathrm{T}$ lymphocytes can respond to foreign $\mathrm{MHC}$ complexed with foreign peptides through the direct pathway of allorecognition and can additionally recognize allopeptides expressed in the context of recipient (self) MHC through the indirect pathway. To better elucidate how indirect pathway-responsive $\mathrm{CD}^{+}{ }^{+} \mathrm{T}$ cells mediate allograft rejection, we isolated and characterized a TH1 T cell line from $B A L B / c$ recipients of $B 10$.A skin that responds to a defined immunodominant, self-restricted allopeptide, I-A $\beta^{\mathrm{k}} 58-71$. When transferred into $\mathrm{BALB} / \mathrm{c}$ severe combined immunodeficiency recipients of B10.A skin allografts, this cell line specifically induced a form of skin graft rejection characterized by the presence of TH1 cytokines, macrophage infiltration, and extensive fibrosis. Recall immune responses and immunofluorescence of the rejecting skin revealed only the presence of the peptide-specific $T$ cells within the recipient animals, with no evidence of a direct pathway alloresponse. These studies demonstrate that $T$ cells reactive to a single self-restricted allopeptide can mediate a form of allogeneic skin graft rejection that exhibits characteristics of a chronic, fibrosing process. (J. Clin. Invest. 1998. 101:1398-1407.) Key words: T lymphocytes • transplantation immunology • cytokines $\bullet$ graft rejection $\bullet$ cellular immunity
\end{abstract}

\section{Introduction}

T lymphocytes are known to be central mediators of allograft rejection $(1,2)$. The majority of recipient $\mathrm{T}$ cells activated in response to an allograft recognize donor peptides complexed with donor MHC molecules expressed directly on the transplanted cells through the direct pathway of allorecognition (3). Recent work has also established that alloreactive $\mathrm{T}$ cells can respond to processed donor peptides presented in the context of recipient $\mathrm{MHC}$ molecules through the indirect pathway (4-9). The relevance of indirect allorecognition to the rejection process is highlighted by studies demonstrating that immunotherapy targeting peptides presented by the indirect pathway can result in allograft tolerance (10-14).

This work was presented at the annual meeting of the American Society of Transplant Physicians in Chicago, IL, in May 1997.

Address correspondence to Peter S. Heeger, M.D., Cleveland VA Medical Center, 111K(W), 10701 East Blvd., Cleveland, OH 44106. Phone: 216-791-3800 ext. 5278; FAX: 216-231-3420; E-mail: heeger. peter@cleveland.va.gov

Received for publication 11 June 1997 and accepted in revised form 21 January 1998.

The Journal of Clinical Investigation

Volume 101, Number 6, March 1998, 1398-1407

http://www.jci.org
The specific role played by $\mathrm{CD}^{+} \mathrm{T}$ cells responsive to determinants presented via indirect allorecognition is only partially understood. Elegantly designed experiments using MHC II knockout mice as skin donors have clearly shown that these T cells participate in graft rejection, and suggest that they provide help for the induction of a $\mathrm{CD}^{+}$, direct pathway-responsive effector cell population that in turn rejects the allograft (9). Additionally, there is some evidence to suggest that $\mathrm{CD}^{+}$, indirect pathway-responsive $\mathrm{T}$ cells can mediate graft rejection without $\mathrm{CD}^{+}$cells $(15,16)$, but the rejection process under these circumstances seems to be inefficient, at best. In addition, the effector mechanisms involved are poorly understood, especially in light of the fact that without direct allorecognition, there can be no direct cytotoxicity of the transplanted cells. Furthermore, T cells responding to self-restricted allopeptides have been hypothesized to be specifically pathogenic in the development of chronic allograft rejection (14). However, despite much speculation, there is little experimental evidence to support this contention.

To provide further insight into the role of $\mathrm{CD} 4^{+} \mathrm{T}$ cells responding to indirect pathway determinants as potential mediators of allograft rejection, we have been studying rejection of B10.A skin by recipient BALB/c mice $(6,7,17)$. In this model, indirect alloreactivity is focused towards a defined, MHC II donor-derived, immunodominant determinant (I-A $\beta^{\mathrm{k}} 58-71$ [I-Ap] $)^{1}$ expressed in the context of recipient $\mathrm{MHC}$ II $(6,7$, 17). In these studies, we provide evidence that TH1 T cells specific for I-Ap, without concomitant reactivity to alloantigens presented by the direct pathway, can clearly mediate skin graft rejection. Moreover, the studies suggest that these T cells produce a form of rejection that exhibits features of a chronic process characterized by mononuclear infiltration and fibrosis, but only slow clinical deterioration of the graft itself. The work provides an ideal model system for isolating and studying the mechanisms of indirect pathway-responsive $\mathrm{T}$ cells as mediators of allograft rejection.

\section{Methods}

Animals. Female BALB/c $\left(H-2^{\mathrm{d}}\right), \mathrm{BALB} / \mathrm{c}$ severe combined immunodeficient (SCID) $\left(H-2^{\mathrm{d}}\right), \mathrm{C} 57 \mathrm{BL} / 6\left(\mathrm{~B} 6, H-2^{\mathrm{b}}\right)$, and B10.A $\left(H-2^{\mathrm{a}}\right.$; $\left.\mathrm{K}^{\mathrm{k}} \mathrm{A}^{\mathrm{k}} \mathrm{E}^{\mathrm{k}} \mathrm{D}^{\mathrm{d}}\right)$, age 6-8 wk, were purchased from The Jackson Laboratory (Bar Harbor, ME) and maintained in the specific pathogen-free animal facility at the Cleveland Veterans Affairs Medical Center.

Peptides. I-Ap (AEYWNKQYLERTRA) and hen egg white lysozyme 106-116 (HELp; NAWVAWRNRCK) were synthesized by Research Genetics (Huntsville, AL) at $>90 \%$ purity. I-A $\beta^{k} 31-49$

1. Abbreviations used in this paper: APC, antigen-presenting cell; Con A, concanavalin A; DTH, delayed-type hypersensitivity; HELp, hen egg lysozyme peptide 106-116; I-Ap, peptide I-A $\beta^{\mathrm{k}} 58-71$; RT, reverse transcription; SCID, severe combined immunodeficiency; TCR, $\mathrm{T}$ cell receptor; $\mathrm{V} \beta$, variable region $\beta$ chain. 
and I-A $\alpha^{\mathrm{k}} 49-63$ were kindly supplied by Gilles Benichou, University of California, San Francisco, CA.

Placement and evaluation of skin grafts. Full-thickness trunk skin allografts were placed using standard techniques $(2,17)$. Skin was harvested from killed donor mice, the subcutaneous fat was removed, and the skin was cut into $0.5-\mathrm{cm}^{2}$ pieces and placed in sterile PBS until used for transplantation $(<30 \mathrm{~min})$. Recipient mice were anesthetized with pentobarbital ( $50 \mu \mathrm{g} / \mathrm{g}$ body wt) and shaved around the chest and abdomen. The skin allograft was placed in a slightly larger graft bed prepared over the chest of the recipient and secured using Vaseline gauze and a bandage. Bandages were removed on day 7 , and the grafts were then visually scored daily for evidence of rejection. The allograft was considered fully rejected when it was $>50 \%$ necrotic. In selected animals, allograft rejection was confirmed histologically. Skin grafts were placed on SCID recipients using fully sterile techniques.

Histologic evaluation of skin. Skin tissue was harvested from killed mice and prepared for histologic analysis by standard techniques. A portion of the skin tissue was frozen in OCT compound (Miles Laboratories Inc., Elkhart, IN) for immunofluorescence studies. Sections were stained with hematoxylin and eosin. Histologic evaluation of the skin was performed in a blinded fashion by a boardcertified dermatopathologist (A. Gilliam).

Preparation of stimulator cells. Splenic stimulator cells were prepared by incubation with mitomycin $\mathrm{C}$ (Boehringer Mannheim Biochemicals, Indianapolis, IN) at $50 \mu \mathrm{g} / \mathrm{ml}$ for $20 \mathrm{~min}$ at $37^{\circ} \mathrm{C}$ in PBS, followed by three washes in HBSS. The cells were counted by trypan blue exclusion and diluted for use in the various assays.

Isolation and maintenance of SH10 T cell line. SH10 T cell line was prepared using cells isolated from the draining lymph nodes of a $\mathrm{BALB} / \mathrm{c}$ mouse rejecting a B10.A trunk skin allograft using previously published techniques (18). The cell line was maintained on a monthly cycle by stimulation in complete RPMI (10\% FCS, $5 \%$ NCTC medium, 2-mercaptoethanol, penicillin, and streptomycin) with syngeneic mitomycin $\mathrm{C}$-treated splenocytes as antigen-presenting cells (APCs) and $2 \mu \mathrm{M}$ I-Ap for $10 \mathrm{~d}$, followed by two consecutive feeding cycles with $2 \mathrm{U} / \mathrm{ml}$ recombinant human IL-2 (PharMingen, La Jolla, CA) for $10 \mathrm{~d}$ (without new APCs or antigen).

Proliferation assays. $4-5 \times 10^{4} \mathrm{~T}$ cells were mixed with $4 \times 10^{5}$ syngeneic BALB/c mitomycin C-treated splenocytes as APCs in triplicate in flat-bottomed 96 -well plates with or without $10 \mu \mathrm{M}$ peptide. $1 \mu \mathrm{Ci}\left[{ }^{3} \mathrm{H}\right]$ thymidine was added for the final $16 \mathrm{~h}$ of a $72-\mathrm{h}$ incubation. Plates were harvested, and the incorporated label was measured by liquid scintillation counting.

Antibodies. FITC-conjugated anti-CD8 $\alpha$ (53-6.7), phycoerythrinconjugated anti-CD4 (RMA4-5), FITC-conjugated anti-variable region $\beta$ chain $(\mathrm{V} \beta) 2$ (B20.6), FITC-conjugated anti-V $\beta 4$ (KT4), FITC-conjugated anti-CD3, and FITC-conjugated anti-CD45RB were purchased from PharMingen. FITC-conjugated anti-CD62 (L-selectin, MEL-14) was a kind gift from Paul Lehmann, Department of Pathology, Case Western Reserve University.

$F A C S^{\circledR}$ analysis. SH10 cells were purified by isolation through Lympholyte M (Cedarlane Labs Ltd., Hornby, Ontario, Canada) and stained in PBS $/ 0.1 \%$ BSA for $30 \mathrm{~min}$ at $4^{\circ} \mathrm{C}$. Single cell suspensions of spleen cells were similarly stained after red blood cell lysis. After three washes in PBS, the cells were fixed in fresh $1 \%$ paraformaldehyde and stored at $4^{\circ} \mathrm{C}$ in the dark until analyzed (within $24 \mathrm{~h}$ ). Analysis was performed using a FACScan ${ }^{\circledR}$ (Becton Dickinson, San Jose, CA) and accompanying software using 5,000 ungated cells.

Direct immunofluorescence. Frozen sections of skin tissue were fixed in acetone at $-20^{\circ} \mathrm{C}$ for $30 \mathrm{~s}$ and then washed three times in PBS for 5 min per wash. The tissue sections were incubated with FITC-conjugated anti-V $\beta 2$ or anti-V $\beta 4$ antibodies at 1:100 dilution in $\mathrm{PBS} / 0.1 \% \mathrm{BSA}$ for $30 \mathrm{~min}$ at room temperature and then washed three times in PBS. Slides were examined and photographed with an immunofluorescence microscope.

Preparation of RNA. Lympholyte M-purified T cells or skin tissue were homogenized in TRIzol RNA preparation reagent (GIBCO
BRL, Gaithersburg, MD) and total RNA was isolated as instructed by the manufacturer.

Reverse transcription (RT) PCR for cytokine message and T cell receptor $(T C R) V \beta$ gene expression. First-strand cDNA and RT-PCR for cytokine or TCR V $\beta$ gene expression was performed using previously described oligonucleotide primers (18-21). Primers for $\beta$-actin, IFN- $\gamma$, IL-2, IL-4, IL-10, TNF- $\alpha$, and TGF- $\beta$ were purchased from Stratagene Inc. (La Jolla, CA). PCR was performed in a total volume of $50 \mu \mathrm{l}$ as follows: $94^{\circ} \mathrm{C}$ denature for $5 \mathrm{~min}, 35$ cycles of $94^{\circ} \mathrm{C}$ for 1 $\min , 55^{\circ} \mathrm{C}$ for $2 \mathrm{~min}$, and $72^{\circ} \mathrm{C}$ for $2 \mathrm{~min}$, followed by a 20 -min extension at $72^{\circ} \mathrm{C} .15 \mu \mathrm{l}$ of each sample was run on a $1.5 \%$ agarose gel and photographed. Selected RT-PCR products were blotted onto nitrocellulose membranes and probed with an internal constant region $\beta$ oligonucleotide as described previously (20).

Delayed-type hypersensitivity (DTH) assay. DTH was performed as described previously (18). Briefly, $1-2 \times 10^{6} \mathrm{SH} 10$ cells plus $10 \mu \mathrm{M}$ I-Ap in a total volume of $25 \mu \mathrm{l}$ of PBS were injected into the right ear of three naive BALB/c mice, and $1-2 \times 10^{6} \mathrm{SH} 10$ cells plus control peptide were injected into the left ear. Ear thickness was measured before immunization and at $48 \mathrm{~h}$ with an engineer's micrometer by an investigator blinded to the experimental groups, and the results were expressed as difference in mean values of the thickness between the ears before injection and at the 48-h time point. Ear tissue was placed in formalin, cut, and stained with hematoxylin and eosin for histologic analysis.

Cytotoxicity assays. Cytotoxicity was performed as published by Matzinger (22). BALB/c or B10.A target cells were made by incubating $2 \times 10^{6}$ splenocytes with $1 \mu \mathrm{g} / \mathrm{ml}$ LPS (Sigma Chemical Co., St. Louis, MO) in $2 \mathrm{ml}$ of HL-1 medium (BioWhittaker, Inc., Walkersville, MD) for $48-72 \mathrm{~h}$. $\left[{ }^{3} \mathrm{H}\right]$ thymidine $10 \mu \mathrm{Ci}$ with or without $10 \mu \mathrm{M}$ I-Ap (or control peptide) was added for the final $12 \mathrm{~h}$. $\left[{ }^{3} \mathrm{H}\right]$ thymidinelabeled A20 cells $\left(H-2^{\mathrm{d}}, \mathrm{B}\right.$ cell lymphoma obtained from American Type Culture Collection, Rockville, MD) were used as targets in some experiments. After three washes in HBSS medium, the target cells were counted, and 10,000 cells were placed in each well of a round-bottomed 96-well plate. Positive control BALB/c anti-B10.A killer cells were produced by incubating $8 \times 10^{6} \mathrm{BALB} / \mathrm{c}$ spleen cells with $4 \times 10^{6} \mathrm{~B} 10$.A stimulator cells in $2 \mathrm{ml}$ of complete RPMI at $37^{\circ} \mathrm{C}$ $5 \% \mathrm{CO}_{2}$ for $5 \mathrm{~d}$, and then washed and counted. SH10 cells or BALB/c anti-B10.A killer cells were added to the targets at various $\mathrm{E} / \mathrm{T}$ ratios and incubated at $37^{\circ} \mathrm{C} 5 \% \mathrm{CO}_{2}$ for $5 \mathrm{~h}$. The plates were harvested and counted by liquid scintillation, and the percentage of cytotoxicity was calculated as described (22).

ELISA assays. 300,000 SH10 cells were mixed with $3 \times 10^{6}$ mitomycin C-treated BALB/c stimulator cells with or without $10 \mathrm{mM}$ peptide in $2 \mathrm{ml}$ of complete $\mathrm{T}$ cell medium in a 24-well plate. The supernatants were harvested at $48 \mathrm{~h}$ and studied in a sandwich ELISA for cytokine production. Immulon-4 plates (PGC Scientific, Gaithersburg, MD) were coated with capture antibody in PBS overnight. R46A2 $(4 \mu \mathrm{g} / \mathrm{ml})$ for IFN- $\gamma$, 11B11 $(1 \mu \mathrm{g} / \mathrm{ml})$ for IL-4, and TRFK5 $(2.5 \mu \mathrm{g} / \mathrm{ml})$ for IL-5 were produced and isolated in our laboratory from hybridomas. Anti-IL-2 (3 $\mu \mathrm{g} / \mathrm{ml})$, anti-IL-10 $(4 \mu \mathrm{g} / \mathrm{ml})$, and anti-TNF- $\alpha(4 \mu \mathrm{g} / \mathrm{ml})$ capture antibodies were purchased from PharMingen. After washing with PBS, cytokine standards (PharMingen) and the culture supernatants were added to wells in duplicate and incubated at $4{ }^{\circ} \mathrm{C}$ overnight. After three washes in PBS $/ 0.025 \%$ Tween (PBST), second antibodies were added for $4 \mathrm{~h}$ at room temperature. XMG1.2-biotin (produced in our laboratory) was used for IFN- $\gamma$. Other detection antibodies were purchased from PharMingen: rat anti-mouse IL-4-biotin $(1 \mu \mathrm{g} / \mathrm{ml})$ was used for IL-4, rat antimouse IL-2-biotin $(1 \mu \mathrm{g} / \mathrm{ml})$ was used for IL-2, rat anti-mouse IL-10biotin $(2 \mu \mathrm{g} / \mathrm{ml})$ was used for IL-10, rat anti-mouse IL-5-biotin $(2 \mu \mathrm{g} / \mathrm{ml})$ was used for IL-5, and rat anti-mouse TNF- $\alpha$-biotin $(2 \mu \mathrm{g} / \mathrm{ml})$ was used for TNF- $\alpha$. The plates were again washed three times in PBST, and streptavidin-alkaline phosphatase (1:2,000 dilution; DAKO Corp., Carpinteria, CA) was added for $1 \mathrm{~h}$. The plates were developed with a $p$-nitrophenyl phosphate substrate (Research Organics Inc., Cleveland, $\mathrm{OH}$ ), and the OD was read at $405 \mathrm{~nm}$. 
Table I. Cytokine Production by T Cells during Rejection of B10.A Skin Grafts (Spots per $10^{6}$ T Cells Plated)

\begin{tabular}{lrccc}
\hline Cytokine & I-Ap & HELp & B10.A splenocytes & Con A \\
\hline IFN- $\gamma$ & 24 & $<5$ & 3830 & $>5000$ \\
IL-2 & 22 & $<5$ & 990 & $>5000$ \\
IL-5 & $<5$ & $<5$ & $<5$ & $>5000$
\end{tabular}

Purified T cells $\left(>95 \% \mathrm{CD}^{+}\right.$by $\left.\mathrm{FACS}^{\circledR}\right)$ obtained from draining lymph nodes of BALB/c mice on day 11 after placement of B10.A skin were studied in IFN- $\gamma$, IL-2, and IL-5 ELISA spot assays in response to $10 \mu$ M I-Ap or HELp, B10.A stimulator cells, or $2 \mu \mathrm{M}$ Con A. Values are the means of duplicate wells counted by a computer-assisted image analyzer and are representative of five individual experiments. Intrawell variability was $<10 \%$. No detectable response ( $<1$ per million) to I-Ap was noted in naive animals or in animals rejecting control B6 allografts (not shown).

ELISA spot assays. ELISA spot plates (Polyfiltronics, Inc., Rockland, MA) were coated with capture antibodies in sterile PBS overnight. R46A2, produced and isolated in our laboratory from a hybridoma, was used at $4 \mu \mathrm{g} / \mathrm{ml}$ for IFN- $\gamma$. Anti-IL-2 capture antibody (JES6-1A12; PharMingen) was used for IL-2, and anti-IL-5 capture antibody (TRFK4; PharMingen) was used for IL-5. The plates were blocked for $1 \mathrm{~h}$ with sterile PBS/1\% BSA and washed with sterile PBS. Various dilutions of splenocytes, lymph node cells, or SH10 T cells $\left(0.25-8 \times 10^{5} / \mathrm{ml}\right)$ in $200 \mu$ l of HL-1 medium were placed in each well with or without antigen and irradiated APCs (in duplicate), and incubated at $37^{\circ} \mathrm{C}$ for $24 \mathrm{~h}$ in $5 \% \mathrm{CO}_{2}$. After washing with $\mathrm{PBS} / 0.1 \%$ Tween, detection antibodies were added overnight. XMG1.2-horseradish peroxidase (produced in our laboratory from a hybridoma) was used for IFN- $\gamma$, rat anti-mouse IL-2-biotin (JES6-5H4; PharMingen) was used for IL-2, and rat anti-mouse IL-5 (TRFK5; PharMingen) was used for IL-5. Streptavidin-horseradish peroxidase (DAKO Corp; $1: 2,000$ in $\mathrm{PBS} / 0.1 \%$ Tween for $2 \mathrm{~h}$ at room temperature) was used as a third reagent for IL-2, and anti-IgG2a-horseradish peroxidase (Zymed Laboratories Inc., South San Francisco, CA; 1:300 in $\mathrm{PBS} / 0.1 \%$ Tween for $2 \mathrm{~h}$ at room temperature) was used as a third reagent for IL-5. The plates were developed using $800 \mu$ l AEC (Pierce Chemical Co., Rockford, IL; $10 \mathrm{mg}$ dissolved in $1 \mathrm{ml}$ dimethyl formamide) mixed in $24 \mathrm{ml} 0.1 \mathrm{M}$ sodium acetate, $\mathrm{pH}$ 5.0, plus $12 \mu \mathrm{H}_{2} \mathrm{O}_{2}$. The resulting spots were counted on a computer-assisted ELISA spot image analyzer (developed using software from Optimas Corp., Bothell, WA), which is designed to detect ELISA spots using predetermined criteria based on size, shape, and colorimetric density.

\section{Results}

Isolation and characterization of SH10 cells. We initially isolated draining lymph node $\mathrm{T}$ cells $\left(>95 \% \mathrm{CD}^{+}, 66 \% \mathrm{CD}^{+}\right.$,
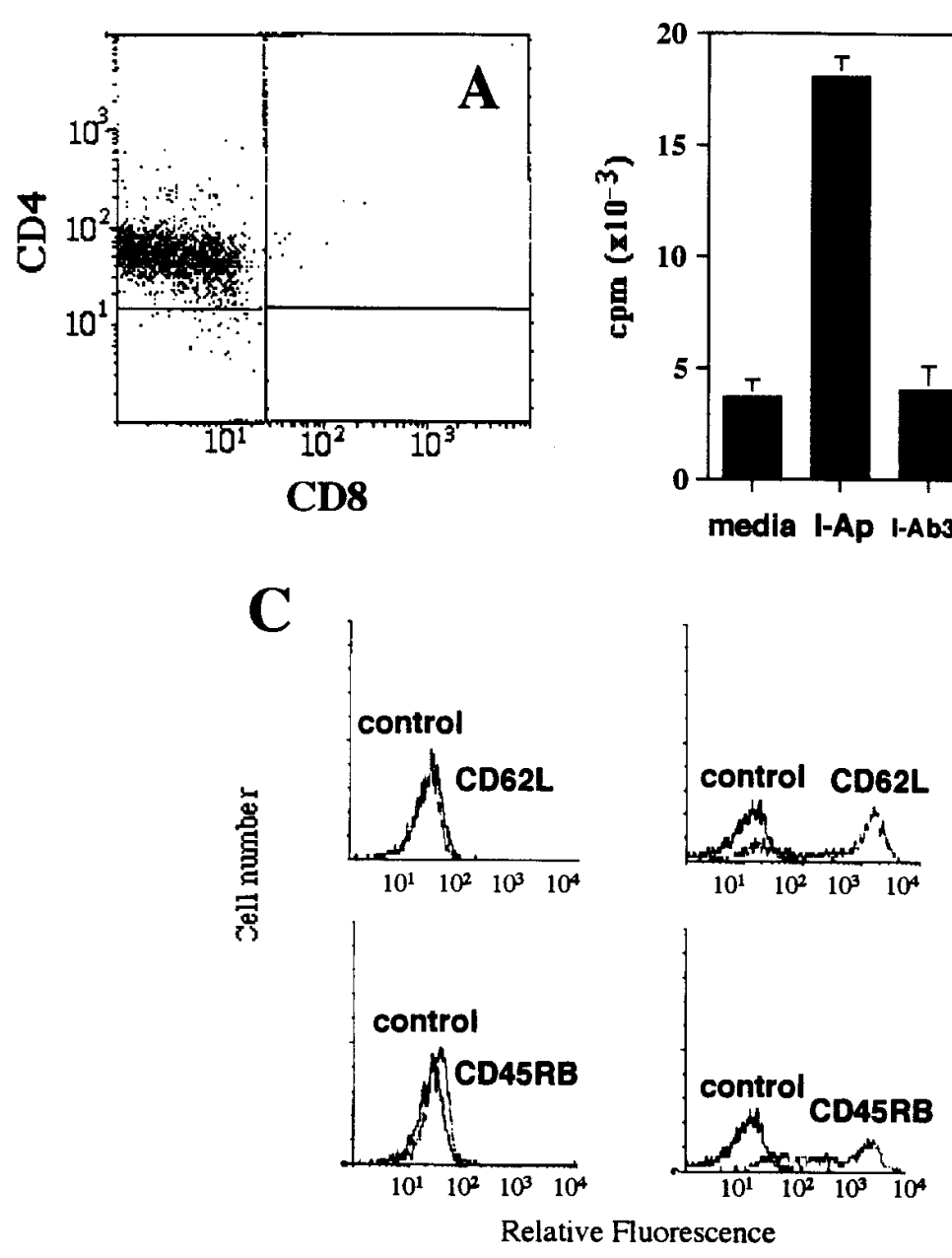

SH10 cells BALB/c splenocytes

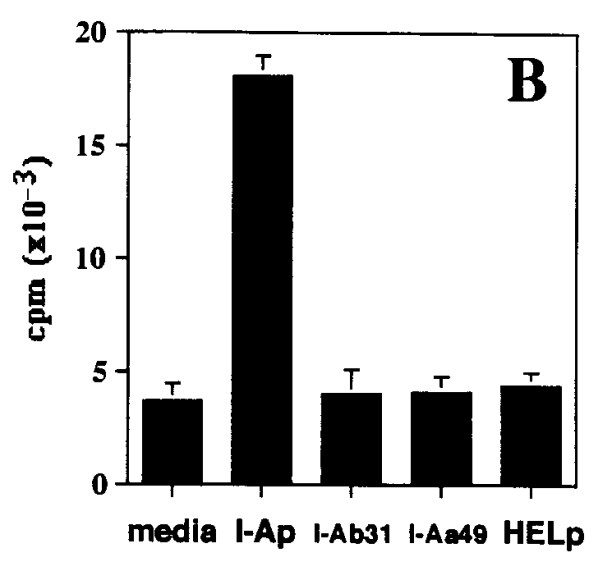

Figure 1. Surface phenotype and antigen specificity of SH10 cells. (A) Two-color FACS $^{\circledR}$ analysis of SH10 cells stained with FITC-conjugated anti-CD8 and phycoerythrin-conjugated anti-CD4. (B) 72-h proliferative responses of SH10 cells to $10 \mu \mathrm{M}$ I-Ap, or to control peptides I-A $\beta^{\mathrm{k}} 31-49(I-A b 31), \mathrm{I}-\mathrm{A} \alpha^{\mathrm{k}} 49-63$ (I-Aa49), and HELp. (C) FACS ${ }^{\circledR}$ analysis of SH10 cells (left) or spleen cells from a naive BALB/c mouse (right) stained with FITC-anti-CD62L (top) or FITC-antiCD45RB (bottom). 
Table II. SH10 Cells Express a TH1 Cytokine Profile

\begin{tabular}{lccc}
\hline & \multicolumn{3}{c}{ Antigenic stimulus } \\
\cline { 2 - 4 } Cytokine & $p g / m l$ & $\mathrm{I}$-Ap $(3 \mu \mathrm{M})$ & $\mathrm{HELp}(3 \mu \mathrm{M})$ \\
\hline & 9 & 7200 & $p g / m l$ \\
IFN- $\gamma$ & 9150 & $<5$ \\
IL-2 & 1600 & $<5$ & 1650 \\
IL-4 & $<5$ & $<5$ & $<5$ \\
IL-5 & $<5$ & $<5$ & $<5$ \\
IL-10 & $<5$ & 400 & $<5$ \\
TNF- $\alpha$ & $<300$ & & $<300$ \\
& &
\end{tabular}

Supernatants of 48-h cultures were studied in sandwich ELISAs as described in Methods. Limit of detection is $5 \mathrm{pg} / \mathrm{ml}$ for IFN- $\gamma$, IL-2, IL-4, IL-5, and IL-10, and $300 \mathrm{pg} / \mathrm{ml}$ for TNF- $\alpha$.

$33 \% \mathrm{CD}^{+}$by $\mathrm{FACS}^{\circledR}$, not shown) from BALB/c mice $11 \mathrm{~d}$ after placement of B10.A skin grafts. Table I confirms previous studies (17) that TH1 T cells reactive to I-Ap are present during $\mathrm{BALB} / \mathrm{c}$ rejection of $\mathrm{B} 10$. A skin at a frequency of $\sim 1 / 20,000, \sim 1 \%$ of the response to B10.A splenocytes (direct pathway). We were unable to detect an I-Ap-specific response using splenocytes or isolated $\mathrm{T}$ cells from naive $\mathrm{BALB} / \mathrm{c}$ mice (frequency of $<1 / 500,000$, not shown).

To study the role of I-Ap-specific T cells as potential mediators of allograft rejection, we isolated a $\mathrm{T}$ cell line, SH10, from the draining lymph nodes of $\mathrm{BALB} / \mathrm{c}$ mice rejecting B10.A skin. Fig. 1 shows that $\mathrm{SH} 10$ is $\mathrm{CD}^{+} / \mathrm{CD}^{-}$, and is both $\mathrm{CD}^{-} 2^{-}$and $\mathrm{CD}_{45 \mathrm{RB}^{-}}$, consistent with a memory $\mathrm{T}$ cell surface phenotype. SH10 cells also express CD44 on their surface (data not shown). SH10 cells specifically proliferated in response to I-Ap but not to either of two other $I$ - $A^{\mathrm{k}}$-derived
Table III. SH10 Cells Are I-Ap-specific (Spots per $10^{3} \mathrm{~T}$ Cells Plated)

\begin{tabular}{lccccc}
\hline Cytokine & Media & I-Ap & HELp & B10.A splenocytes & B6 splenocytes \\
\hline IFN- $\gamma$ & $<5$ & 195 & $<5$ & $<5$ & $<5$ \\
IL-2 & $<5$ & 159 & $<5$ & $<5$ & $<5$
\end{tabular}

SH10 cells $\left(10^{3}\right)$ were studied in an IFN- $\gamma$ ELISA spot assay with $\mathrm{BALB} / \mathrm{c}$ spleen cell APCs plus or minus I-Ap $(10 \mu \mathrm{M})$ or HELp (10 $\mu \mathrm{M})$, or with B10.A or B6 stimulator spleen cells. Mean values of duplicate wells counted by an automated image analyzer are shown. Results are representative of three individual experiments. Positive control Con A stimulation of splenocytes consistently showed $>300$ spots per well for all cytokines (not shown). Intrawell variability was $<10 \%$.

peptides or to an unrelated, $H-2^{\text {d }}$-restricted control peptide, HELp (Fig. 1).

The cytokine profile of SH10 cells was next determined by sandwich ELISAs performed on 48-h culture supernatants (Table II). As shown, SH10 cells produced I-Ap-specific IFN- $\gamma$ and IL-2 without IL-4, IL-5, or IL-10, consistent with a TH1 phenotype. Low levels of TNF- $\alpha$ were additionally produced (Table II).

To further validate that SH10 cells were I-Ap-specific and did not cross-reactively respond to intact B10.A alloantigens (direct pathway), we studied SH10-induced IFN- $\gamma$ and IL-2 production using a high resolution ELISA spot assay (Table III). As shown, SH10 cells responded specifically to I-Ap and not to intact B10.A stimulator cells or to control B6 splenocytes (Table III). Approximately $20 \%$ of the SH10 cells produced IFN- $\gamma$ spots in this experiment. We have noted consis-

\section{A DTH}

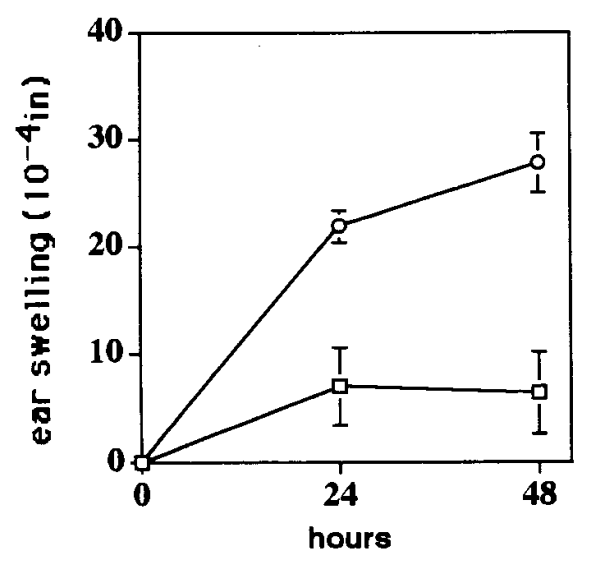

\section{B Cytotoxicity}

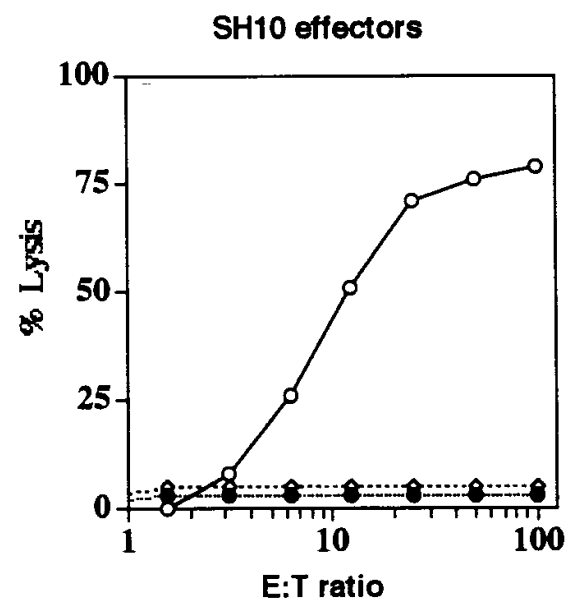

BALB/c anti B10.A effectors

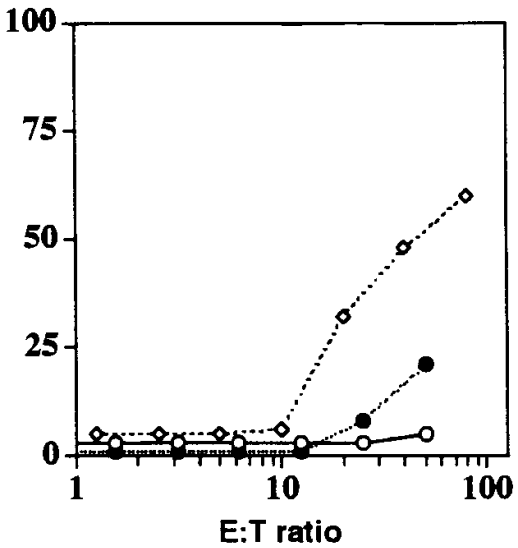

Figure 2. SH10 cells mediate DTH and exhibit cytotoxicity. (A) Ear swelling as a measure of DTH. Values represent the difference in ear thickness for ears injected with SH10 cells plus control HELp $(\square)$ versus ears injected with SH10 cells plus $10 \mu \mathrm{M}$ I-Ap (O). Three animals were tested per group, and the results are representative of three independent experiments. DTH was confirmed by histologic examination of the tissue (not shown). (B) SH10 effector cells were tested for cytotoxicity against syngeneic A20 cells loaded with I-Ap (O) or HELp (๑) or against LPS-induced B10.A spleen cell $(\diamond)$ blasts. BALB/c anti-B10.A cytotoxic T lymphocytes were induced as outlined in Methods and tested for cytotoxicity against the same three targets. Results are representative of two individual experiments. 

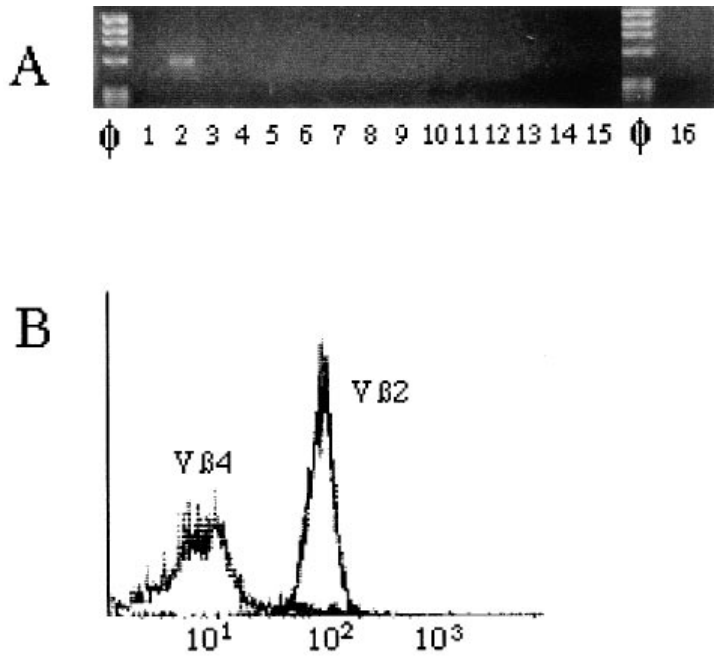

Figure 3. SH10 cells express V $\beta 2$. ( $A$ ) Ethidium bromide-stained agarose gel of RT-PCR products for $\mathrm{V} \beta$ genes expressed by $\mathrm{SH} 10$ cells. Lanes, Individual TCR V $\beta$ gene families tested. The sample also contained a control RT-PCR product for $\beta$-actin (not shown). (B) FACS ${ }^{\circledR}$ analysis of SH10 cells stained with FITC-conjugated anti$\mathrm{V} \beta 2$ or control anti- $\mathrm{V} \beta 4$ antibodies.

tently that between 20 and $70 \%$ of the SH10 cells specifically responded to I-Ap in an individual experiment (this has been repeated more than five times) irrespective of the number of passages in culture (the cells have been maintained for $>20$ passages), and that there has never been a detectable antiB10.A or anti-B6-specific response. Furthermore, we found that both the cytokine profile and the detected frequency of spots were similar whether we used BALB/c splenocytes or A20 B cell lymphoma cells $\left(H-2^{\mathrm{d}}\right)$ as APCs (not shown).

Further characterization revealed that SH10 cells were capable of mediating DTH in response to I-Ap but not a control HELp (Fig. 2 A). Histologic evaluation revealed perivascular edema and mononuclear cell infiltration consistent with DTH (not shown). In addition, SH10 cells were capable of mediating cytotoxicity of I-Ap-loaded A20 $\left(H-2^{\mathrm{d}}\right)$ target cells (indirect recognition) but not B10.A target cells (direct recognition). Control BALB/c killer cells induced by $5 \mathrm{~d}$ exposure to B10.A
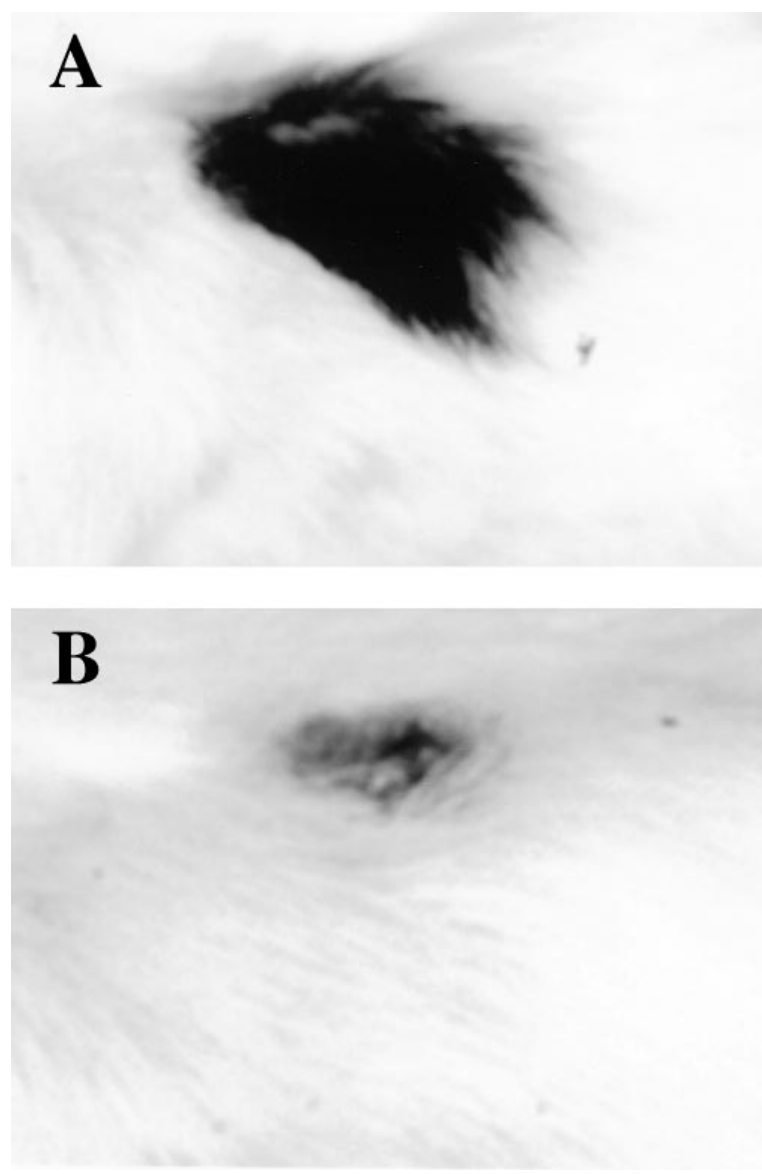

Figure 4. SH10 cells reject B10.A skin on BALB/c SCID recipient mice. $(A)$ Intact B10.A skin graft on a control BALB/c SCID recipient mouse. $(B)$ Rejected B10.A skin graft on a BALB/c SCID recipient mouse adoptively transferred with SH10 cells (day 18 after transfer). Representative of three individual animals.

stimulator cells in vitro provided a positive control for the assay, and lysed the B10.A targets (Fig. 2 B).

TCR V $\beta$ gene expression by SH10 cells as determined by RT-PCR (Fig. $3 A$ ) revealed a restriction to V $\beta 2$. Cell surface expression of $\mathrm{V} \beta 2$ was then confirmed by $\mathrm{FACS}^{\circledR}$ (Fig. 3 B).

Table IV. Skin Graft Survival of BALB/c SCID Recipient Mice

\begin{tabular}{ccccc}
\hline \multicolumn{1}{c}{ Recipient } & Donor graft & Cells transferred & Graft Survival & Comments \\
\hline & & & $d$ & \\
BALB/c SCID & B10.A & None & $>120,>120,>120,>120$ & $\begin{array}{l}n=4 \text {, Histology normal } \\
\text { BALB/c SCID }\end{array}$ \\
& B10.A & SH10 & $13,18,18,20$, & $\begin{array}{c}\text { All grafts showed histologic evidence } \\
\text { of fibrosis and macrophage infiltration }\end{array}$ \\
BALB/c SCID & B10.A & IID2 & $>120,>120,>120$ & $n=3$, Histology normal \\
BALB/c SCID & B10.A & Naive BALB/c T cells & $11,12,12,13,11,12$ & $n=6$, Histology revealed necrosis and \\
massive mononuclear cell infiltration & $n=3$, Histology normal \\
BALB/c SCID & B6 & SH10 & $>120,>120,>120$ & $n$ \\
\hline
\end{tabular}

$5-10 \times 10^{6} \mathrm{~T}$ cells were adoptively transferred by tail vein injection into BALB/c SCID recipients of skin grafts 10-21 d after placement of the grafts. * The three grafts that did not fully reject exhibited focal areas of necrosis and hair loss. Animals in this group were killed at the time of rejection or after day 45 , and the grafts were processed for histologic analysis. 
SH10 cells mediate skin graft rejection in BALB/c SCID recipient mice. To test whether SH10 cells could mediate graft rejection, we first placed B10.A or control B6 trunk skin allografts on recipient BALB/c SCID mice. All skin became fully engrafted with normal hair growth (Fig. $4 A$ ) and without visual evidence of rejection (selected animals followed for $>6$ mo). 10-21 d after placement of B10.A skin, engrafted BALB/c SCID recipients were adoptively transferred with either $5-10 \times$ $10^{6} \mathrm{SH} 10$ cells or naive unfractionated BALB/c T cells by intravenous injection into the tail vein. Transfer of SH10 cells induced B10.A skin graft rejection that was noted on days 13-20 in four of seven animals (Fig. $4 \mathrm{~B}$, and Table IV). The three others exhibited focal evidence of hair loss and/or necrosis within the graft tissue for up to $45 \mathrm{~d}$ after cell transfer, at which time the animals were killed. SH10 cells did not reject control B6 skin $(n=3)$, and intravenous adoptive transfer of a $\mathrm{CD}^{+} H-2^{\mathrm{d}}$-restricted, TH1, ovalbumin-specific cell line (IID2, kindly provided by Paul Lehmann) did not result in B10.A graft rejection ( $n=3$, animals followed for $>120 \mathrm{~d}$ ). BALB/c SCID recipients of B10.A grafts adoptively transferred with unfractionated naive $\mathrm{BALB} / \mathrm{c} \mathrm{T}$ cells rapidly rejected the allografts, by day $13(n=6$, Table IV).

To circumvent the possibility that the adoptively transferred SH10 cells were unable to home reliably to the skin tissue (thus potentially accounting for the incomplete rejection in three cases), we performed additional experiments in which we directly injected SH10 cells into skin grafts placed on BALB/c SCID recipients. Three of three B10.A grafts showed focal evidence of hair loss and necrosis at the site of injection within 2 wk of the intradermal graft injection. However, injection of SH10 cells into BALB/c SCID recipients of control B6 grafts did not result in rejection $(n=3)$.

Recall immune responses in the $B A L B / c S C I D$ recipients of SH10 cells. To confirm that I-Ap-specific T cells were present in the mice rejecting the skin grafts, and to rule out the possibility that the recipients developed a cross-reactive direct pathway (anti-B10.A) alloresponse in vivo, we next performed a recall ELISA spot assay using spleen cells obtained from the recipient animals. As shown in Table V, spleen cells from the SCID recipient mice rejecting B10.A grafts responded only to I-Ap, and produced IFN- $\gamma$ and IL-2 (without IL-5), consistent with the original phenotype of the adoptively transferred SH10 cells. There was essentially no recall response to B10.A splenocytes, confirming a lack of direct pathway alloreactivity. Spleen cells from control graft recipients given no cells by
Table V. Splenic Recall Responses after SH10-mediated Rejection of B10.A Skin Grafts

\begin{tabular}{lcrc}
\hline \multicolumn{1}{c}{ Cells transferred } & Cytokine & I-Ap & B10.A splenocytes \\
\hline SH10 & IFN- $\gamma$ & 1254 & $<5$ \\
& IL-2 & 670 & 20 \\
& IL-5 & $<5$ & $<5$ \\
None & IFN- $\gamma$ & $<5$ & $<5$ \\
& IL-2 & $<5$ & $<5$ \\
& IL-5 & $<5$ & $<5$ \\
Unfractionated T cells & IFN- $\gamma$ & $<5$ & $>2000$ \\
& IL-2 & $<5$ & $>2000$ \\
& IL-5 & $<5$ & $<5$ \\
\hline
\end{tabular}

Spleen cells of a B10.A-grafted BALB/c SCID recipient of SH10 cells (top) were obtained at the time of rejection (day 18) and studied in a cytokine ELISA spot assay in response to $10 \mu \mathrm{M}$ I-Ap or B10.A stimulator splenocytes. Spleen cells of a control B10.A-grafted BALB/c SCID recipient given no cells (skin grafts intact; middle) and of a recipient with a graft rejected by adoptive transfer of unfractionated syngeneic $\mathrm{T}$ cells (obtained on the day of rejection; bottom) were studied in a similar fashion. Values are the means of duplicate wells counted by a computerassisted image analyzer and are representative of three individual experiments performed on different animals. Intrawell variability was $<10 \%$. Con A stimulation served as a positive control and resulted in $>2,000$ spots per million cells plated for all cytokines.

adoptive transfer did not produce cytokines in response to I-Ap or B10.A stimulators, whereas recipients that rejected grafts after transfer of naive $\mathrm{T}$ cells exhibited a strong antiB10.A response (Table V).

We further confirmed the exclusive presence of SH10 cells in recipient mice by $\mathrm{FACS}^{\circledR}$ analysis of responder splenocytes (Fig. 5). Spleen cells from SH10 recipients of B10.A grafts contained only $\mathrm{V} \beta 2$-expressing $\mathrm{CD}^{+}{ }^{+} \mathrm{T}$ cells, the TCR V $\beta$ gene expressed on SH10 cells. In contrast, however, splenocytes from animals adoptively transferred with unfractionated $\mathrm{T}$ cells contained both $\mathrm{V} \beta^{+}$and $\mathrm{V} \beta 2^{-} \mathrm{CD}^{+} \mathrm{T}$ cells. Agematched control SCID mice contained no $\mathrm{CD}^{+} \mathrm{T}$ cells in their spleens.

Histologic evaluation of the allografts. Portions of skin tissue from all animals were then studied in a blinded fashion by a dermatopathologist (A. Gilliam). Visually normal B10.A

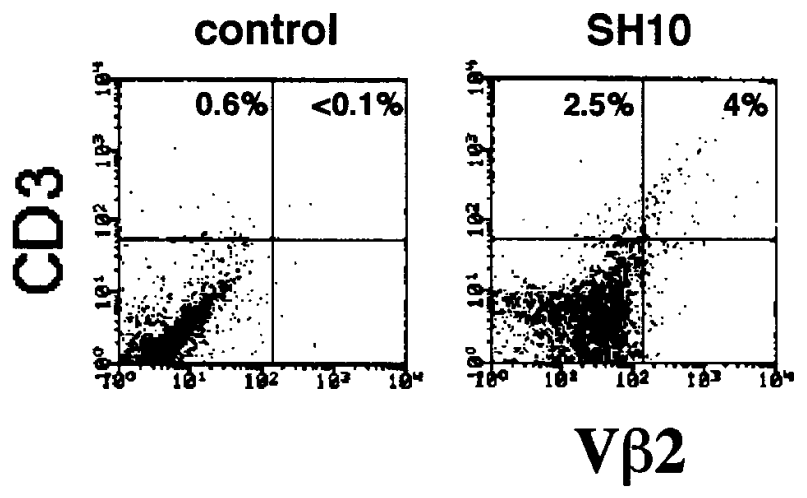

\section{unfractionated T cells}

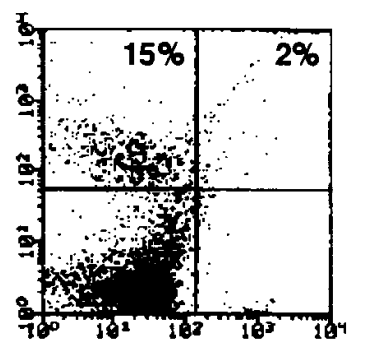

Figure 5. Only $\mathrm{V} \beta 2^{+} \mathrm{T}$ cells are detectable in the graft recipients adoptively transferred with SH10 cells. Representative two-color FACS ${ }^{\circledR}$ analyses of spleen cells obtained from BALB/c SCID mice stained with phycoerythrin-anti-CD3 and FITCanti-V $\beta 2$. Left, Control naive SCID mouse; middle, SCID recipient of B10.A graft rejected by adoptive transfer of SH10 cells; right, SCID recipient of B10.A graft rejected by adoptive transfer of unfractionated $\mathrm{T}$ cells. 

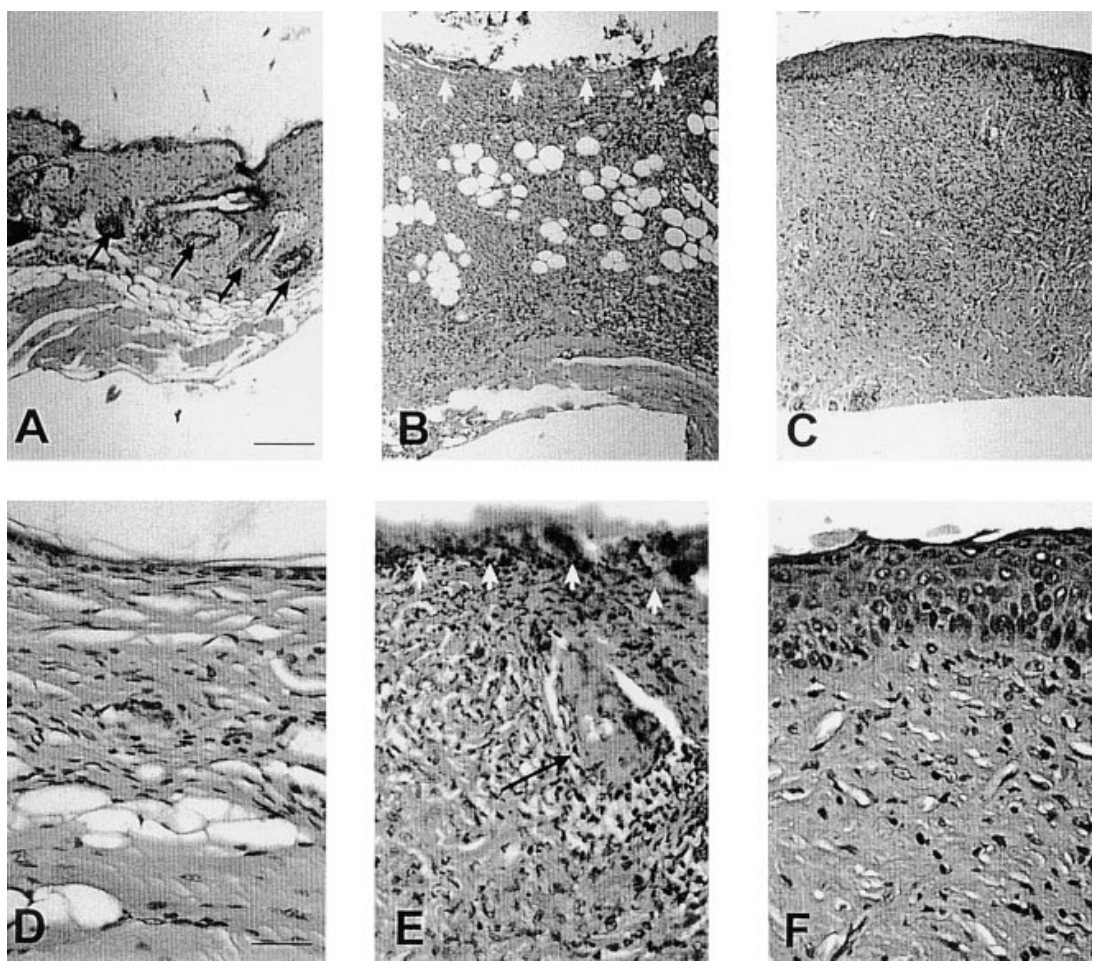

Figure 6. SH10 cell-mediated skin graft rejection exhibits distinct histopathologic features. $(A-F)$ B10.A skin grafts placed on BALB/c SCID recipients. $A$ and $D$, No rejection at $30 \mathrm{~d}$ after placement of skin grafts. $B$ and $E$, Rejection at $10 \mathrm{~d}$ after adoptive transfer of naive BALB/c T cells. Note extensive necrosis of epidermis (white arrows) and hair follicle (black arrow). $C$ and $F$, Rejection at $18 \mathrm{~d}$ after adoptive transfer of SH10 cells. Note extensive dermal fibrosis with infiltration by mononuclear cells and absence of hair follicles. Hematoxylin and eosin; bar for $A-C, 180$ $\mu \mathrm{m}$, bar for $D-F, 50 \mu \mathrm{m}$. skin grafts in BALB/c SCID recipients adoptively transferred with no cells appeared histologically normal as well (Fig. $6 \mathrm{~A}$ and $D$ ). Hair follicles were preserved (Fig. $6 A$, arrows), and the epidermis and dermis were normal in thickness and without evidence of necrosis or fibrosis. Histology of rejected B10.A grafts by naive BALB/c T cells, shown in Fig. $6 B$ and $E$, revealed a prominent mononuclear cell infiltration and necrosis of the epidermis (white arrows), with destruction/necrosis of a hair follicle (Fig. 6 E, black arrow). Neutrophils were concentrated in the areas of necrosis. In contrast, although B10.A skin from an animal that received SH10 cells had a markedly expanded dermal layer with a prominent mononuclear cell infiltrate (Fig. 6, $C$ and $F$ ), the graft did not exhibit evidence of graft necrosis. Five of the seven grafts studied exhibited areas of epidermal hyperplasia. Furthermore, all grafts showed evidence of increased fibrosis compared with the grafts rejected by unfractionated $T$ cells (including those grafts that were not rejected by visual inspection). The dermal fibrosis was seen as dense, thickened, hypercellular stroma with loss of hair follicles (Fig. $6 C$ ). Dermal granulomas were noted as well (not shown). High power view (Fig. $6 F$ ) suggested that the cellular infiltrate consisted predominantly of tissue histiocytes/macrophages and lymphocytes. Histologic examination of the B10.A grafts that were directly injected with SH10 cells revealed focal areas of mononuclear cell infiltration and increased fibrosis.

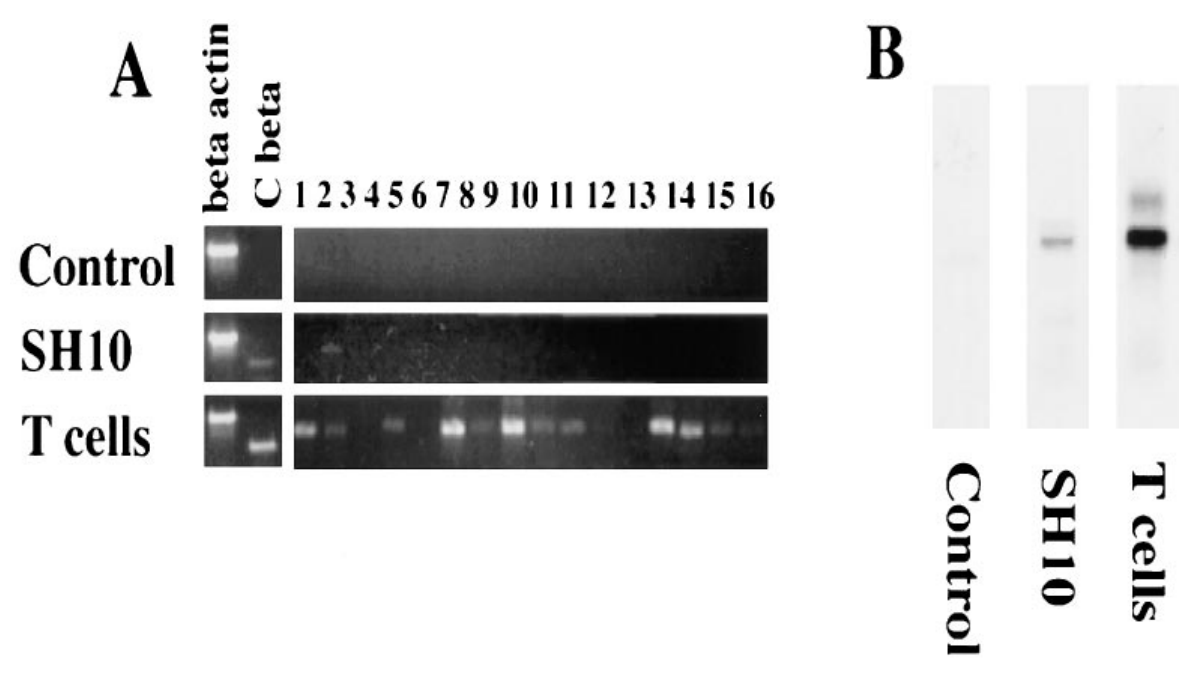

Figure 7. TCR V $\beta 2$ RT-PCR product is present in the skin of animals adoptively transferred with SH10 cells. $(A)$ Ethidium bromide-stained agarose gels of $\mathrm{V} \beta$ gene RT-PCR are shown. Representative gels are shown for control nonrejected B10.A skin (top), rejected B10.A skin on a BALB/c SCID recipient after adoptive transfer of SH10 cells (middle), and rejected B10.A skin on a BALB/c SCID recipient after adoptive transfer of naive $\mathrm{BALB} / \mathrm{c}$ T cells (bottom). Lanes, Individual TCR V $\beta$ gene families tested. $C$ beta, RT-PCR product for constant region of the TCR $\beta$ chain. Results are representative of two to four animals tested per group. (B) Southern blot of V $\beta 2$ RT-PCR products from $A$ probed with an internal constant region oligonucleotide. The detected band is at the predicted size of $310 \mathrm{bp}$. 

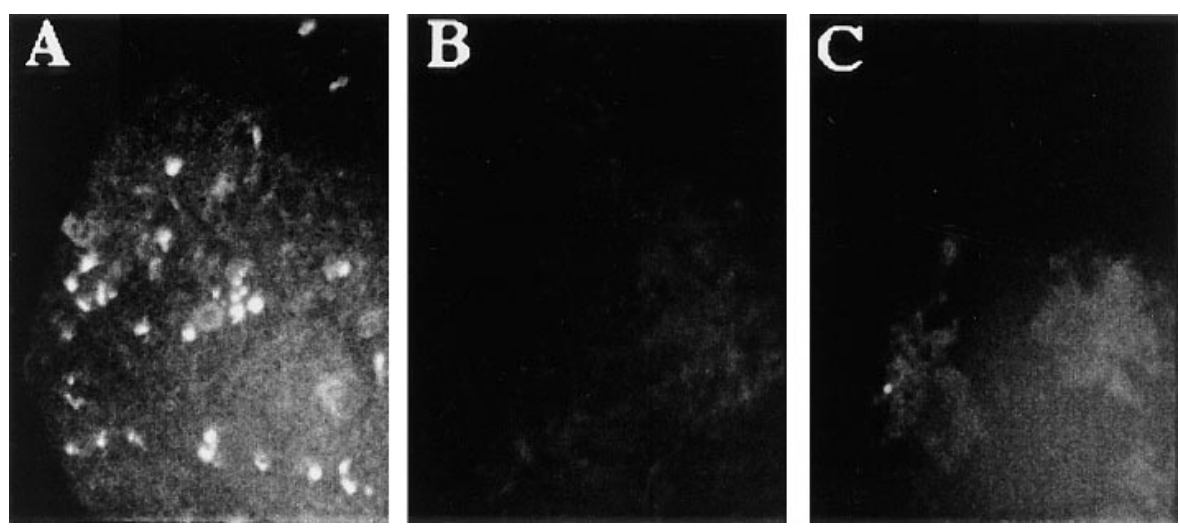

Figure 8. Immunofluorescence of rejected skin reveals the presence of TCR V $\beta 2-$ expressing cells. $(A)$ Rejected B10.A skin after adoptive transfer of SH10 cells stained with FITC-conjugated anti-V $\beta 2$. (B) Rejected B10.A skin after adoptive transfer of SH10 cells stained with FITCconjugated anti-V $\beta 4$. (C) Unrejected control skin stained with FITC-conjugated anti-V $\beta 2$. Results are representative of studies performed on two individual animals; $\times 400$.

SH10 cells were detectable in the rejected skin grafts. The skin grafts of recipients adoptively transferred with SH10 cells were then studied for TCR V $\beta$ gene expression. The skin contained a weak RT-PCR product for V 32 (Fig. 7 B) without other $\mathrm{V} \beta$ genes. No $\mathrm{V} \beta$ gene expression could be detected in the control grafts (Fig. $7 A$ ), whereas multiple $\mathrm{V} \beta$ genes, including $\mathrm{V} \beta 2$, were detected in the grafts rejected by purified naive BALB/c T cells (Fig. 7 C). Specificity of the V 32 PCR product was confirmed by Southern hybridization with an internal oligonucleotide probe as described previously (Fig. $7 \mathrm{C}$ ) (20).

The presence of SH10 cells within the rejected skin was further confirmed by immunofluorescence using specific antiTCR V $\beta$ antibodies (Fig. 8). The rejected B10.A grafts contained V $\beta 2$-expressing T cells (Fig. $8 A$ ), but did not stain with the control anti-V $\beta 4$ antibody. Unrejected, histologically normal skin did not stain with the anti-V $\beta 2$ antibody (Fig. $8 C$ ).

Finally, cytokine gene expression in the skin grafts at the time of rejection was determined by RT-PCR (Fig. 9). Unrejected control skin contained a detectable PCR product for TGF- $\beta$ and a weak band for TNF- $\alpha$. In contrast, rejected B10.A skin grafts obtained from animals adoptively transferred with SH10 cells expressed a strong RT-PCR product for the TH1 cytokine, IFN- $\gamma$, in addition to TNF- $\alpha$ and TGF- $\beta$. Control rejected skin obtained from $\mathrm{BALB} / \mathrm{c}$ recipients of B10.A skin and adoptively transferred with naive BALB/c $T$ cells contained RT-PCR messages for TNF- $\alpha$, TGF- $\beta$, IFN- $\gamma$, and IL-2, and a weak product for IL-10 (message for some type 2 cytokines have been found by others in allografts undergoing rejection) (for a review, see reference 23).

\section{Discussion}

This work clearly demonstrated that $\mathrm{SH} 10$, a T cell line specific for a single MHC II-restricted epitope presented by the indirect pathway of allorecognition, was capable of mediating allogeneic skin graft rejection. SH10 cells responded to I-Ap without cross-reactivity to direct pathway antigens expressed on B10.A spleen cells, and induced rejection of B10.A skin grafts (but not control grafts) on BALB/c SCID recipient animals. Recall responses revealed only I-Ap-specific TH1 immunity without a response to the direct pathway. Only V $\beta 2$ expressing $\mathrm{T}$ cells were found in the recipient animals, and both $\mathrm{V} \beta 2$ and IFN- $\gamma$ were found within the graft itself, consistent with infiltration of SH10 cells.
Our findings confirm and extend previous work showing that reactivity to peptides presented by the indirect pathway is important for allograft rejection $(4,5,8,9,11,16)$. Published experiments from two laboratories explored the role of the indirect pathway in allograft rejection by placing MHC II-deficient skin on MHC I disparate SCID or athymic nude recipients reconstituted with $\mathrm{CD}^{+} \mathrm{T}$ cells $(15,16)$. Both sets of experiments were designed such that $\mathrm{T}$ cell-mediated rejection could only occur if the transferred $\mathrm{CD}^{+} \mathrm{T}$ cells recognized donor MHC I peptides expressed in the context of recipient class II on recipient APCs (indirect recognition). Both sets of experiments concluded that allograft rejection could occur under these circumstances, but that it was delayed markedly (and sometimes did not occur visually) compared with rejection mediated by $\mathrm{CD}^{+}$or $\mathrm{CD}^{+} \mathrm{T}$ cells responding to alloantigens presented by the direct pathway $(15,16)$. Importantly, the specific peptides being recognized could not be defined in these previous experiments. Additionally, there was no direct evidence that peptides derived from donor MHC I (or other,

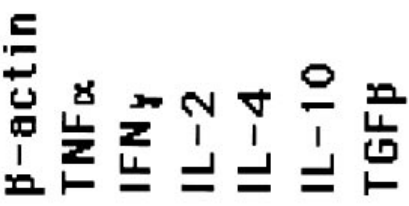

Figure 9. SH10-mediated rejection is associated with IFN- $\gamma$ message in the skin.

Ethidium bromidestained agarose gels of RT-PCR products for cytokines are shown. (A) Unrejected normal B10.A skin on a BALB/c SCID recipient. (B) Rejected B10.A skin on a BALB/c SCID recipient after adoptive transfer of SH10 cells. $(C) \mathrm{Re}-$ jected B10.A skin on a BALB/c SCID recipient after adoptive transfer of naive $\mathrm{BALB} / \mathrm{c}$

T cells. Skin samples were obtained 3 wk after graft placement for group in $A$ and at the time of rejection for $B$ and $C$. (D) Positive control RT-PCR products derived from 48 -h Con A-stimulated BALB/c splenocytes. Results are representative of experiments performed on two to four animals per group. 
minor antigens) presented in the context of recipient MHC II were relevant to the natural rejection process in these model systems. On the other hand, it has been well established that reactivity to I-Ap is immunodominant during naturally occurring rejection of $\mathrm{B} 10 . \mathrm{A}$ skin in recipient $\mathrm{BALB} / \mathrm{c}$ mice $(6,7$, 17). Thus, the finding that $T$ cells responsive to this immunodominant determinant alone can mediate skin graft rejection represents an important step forward.

Interestingly, and similar to the studies noted above (15, 16), our SH10 adoptive transfer experiments did not result in full necrosis of all of the allogeneic skin grafts. Four of the skin grafts became devoid of hair growth, decreased significantly in diameter, and exhibited focal areas of necrosis within $18 \mathrm{~d}$, but three others remained viable for up to $45 \mathrm{~d}$ after cell transfer. However, histologic analysis consistently showed evidence of a mononuclear cell inflammatory infiltrate as well as significant fibrosis, even when the graft was not fully rejected by visual inspection. Thus, subclinical rejection of the skin may be present in a manner analogous to findings noted in several studies of vascularized organ transplants (24-27). Overall, these studies confirm that skin grafts should be evaluated histologically even if the graft appears relatively normal visually.

The specific effector mechanisms involved in SH10-mediated skin allograft rejection remain undefined, but our studies implicate the induction of a DTH response as potentially relevant in this regard. This suggestion is consistent with recently published studies which demonstrated that a panel of $\mathrm{T}$ cell clones reactive to peptides presented by indirect allorecognition could mediate DTH, although their ability to induce/modulate allograft rejection has not yet been reported (28). Activation of SH10 cells may occur within the draining lymph nodes of the allografted animal, as processed B10.A antigens may be presented by host APCs under these circumstances. Alternatively, graft-invading APCs of host origin may allow activation of the SH10 cells within the graft itself. Subsequent production and release of IFN- $\gamma$ by the activated T cells may then induce a proinflammatory TH1 environment, with consequent upregulation of MHC II (29) and costimulatory molecules on the surface of APCs allowing further activation of the invading cells. In addition, the TH1 cytokines may induce the expression and release of chemokines, particularly inflammatory protein 10 and monocyte chemotactic protein 1 , which would then attract macrophages and potentially natural killer cells into the graft site (30). Upon exposure to the proinflammatory environment, the invading macrophages may become activated, forming granulomas and producing $\mathrm{TNF}-\alpha$, which can be directly cytotoxic to the donor cells (15). The proinflammatory environment may additionally induce TGF- $\beta$ expression and subsequent fibrogenesis (31). The presence of messages for IFN- $\gamma$, TNF- $\alpha$, and TGF- $\beta$ in SH10-mediated skin graft rejection (Fig. 9) support this hypothesis. Nitric oxide production and subsequent bystander cytotoxicity may additionally occur (32), leading to necrosis of the foreign cells and subsequent uptake and degradation by the activated macrophages themselves (25).

We cannot entirely rule out cytotoxicity as a mechanism of rejection, as SH10 cells can mediate killing of I-Ap-loaded target cells in vitro. However, preliminary experiments showed that neither Fas ligand nor perforin message was detectable in the SH10-rejected grafts but were found in grafts rejected by unfractionated $T$ cells (not shown), suggesting that cytotoxicity is not a dominant mechanism of rejection under these circumstances. Furthermore, it remains unclear how cytotoxic lysis of
I-Ap-expressing self APCs would result in destruction of allogeneic graft tissue in vivo, even if it is demonstrable in vitro. Delineation of the role of these potential effector mechanisms is ongoing in our laboratory.

Our studies are also consistent with the interpretation that SH10 cells induce a form of chronic skin graft rejection in the SCID recipients. The relatively slow rejection of the skin (compared with that mediated by unfractionated $\mathrm{T}$ cells) and the extensive fibrosis are consistent with a chronic form of skin rejection. Further studies of the effect of SH10 cells in a vascularized organ model of allograft rejection will be required to better elucidate the role of indirect allorecognition and chronic rejection. Importantly, indirect alloreactivity has been postulated to play an immunopathogenic role in the induction of chronic rejection for several years (14), but an inability to measure immune responses to low frequency peptide determinants has technically limited the testing of this hypothesis. The ELISA spot assay and this model system now provide a reliable means for specifically addressing these issues.

In conclusion, these studies reveal that indirect alloreactivity focused towards a single immunodominant determinant is sufficient to induce allogeneic skin graft rejection in mice. This work provides an ideal model system for studying the mechanisms of acute and, potentially, chronic allograft rejection as they apply to the indirect pathway of alloreactivity.

\section{Acknowledgments}

The authors wish to thank E. Biekert and S. Hopfer for their superb technical assistance, and B. Breen for her assistance with preparation of the figures.

This work was supported by the Medical Research Service of the Department of Veterans Affairs, the Skin Disease Research Center (SDRC) at Case Western Reserve University, National Institute of Arthritis and Musculoskeletal and Skin Diseases grant AR-39750, the SDRC Morphology Core facility, the Northeast Ohio Multipurpose Arthritis Center (National Institutes of Health grant AR-20618). P. Heeger is a recipient of a National Institutes of Health K08 award (DK-02125-05), A. Gilliam is a recipient of a Dermatology Foundation Career Development Award, T. Haqqi is a recipient of an Arthritis Foundation Biomedical Science grant, and D. Matesic is a recipient of a National Kidney Foundation fellowship award.

\section{References}

1. Rosenberg, A., and A. Singer. 1992. Cellular basis of skin allograft rejection: an in vivo model of immune-mediated tissue destruction. Annu. Rev. Immunol. 10:333-358.

2. Rosenberg, A. 1991. Skin allograft rejection. In Current Protocols in Immunology. Vol. 1. J. Coligan, A. Kruisbeek, D. Margulies, E. Shevach, and W. Strober, editors. John Wiley \& Sons Inc., Bethesda. 4.4.1-4.4.9.

3. Sayegh, M., B. Watschinger, and C. Carpenter. 1994. Mechanisms of T cell recognition of antigen. Transplantation (Baltimore). 57:1295-1302.

4. Fangmann, F., R. Dalchau, G. Sawyer, C. Priestley, and J. Fabre. 1992. T cell recognition of donor major histocompatibility complex class I peptides during allograft rejection. Eur. J. Immunol. 22:1525-1530.

5. Auchincloss, H., Jr., R. Lee, S. Shea, J. Markowitz, M. Grusby, and L. Glimcher. 1993. The role of indirect recognition in initiating rejection of skin grafts from major histocompatibility complex class II-deficient mice. Proc. Natl. Acad. Sci. USA. 90:3373-3377.

6. Benichou, G., P. Takizawa, C. Olson, M. McMillan, and E. Sercarz. 1992. Donor major histocompatibility complex (MHC) peptides are presented by recipient MHC molecules during graft rejection. J. Exp. Med. 175:305-308.

7. Benichou, G., E. Fedoseyeva, P. Lehmann, C. Olson, H. Geysen, M. McMillan, and E. Sercarz. 1994. Limited T cell response to donor MHC peptides during allograft rejection. J. Immunol. 153:938-945.

8. Liu, Z., Y. Sun, Y. Xi, A. Maffei, E. Reed, P. Harris, and N. Suciu-Foca. 1993. Contribution of direct and indirect recognition pathways to $\mathrm{T}$ cell alloreactivity. J. Exp. Med. 177:1643-1650. 
9. Lee, R., M. Grusby, L. Glimcher, H. Winn, and H. Auchincloss, Jr. 1994. Indirect recognition by helper cells can induce donor-specific cytotoxic T lymphocytes in vivo. J. Exp. Med. 179:865-872.

10. Sayegh, M., N. Perico, L. Gallon, O. Imberti, W. Hancock, G. Remuzzi, and C. Carpenter. 1994. Mechanisms of acquired thymic unresponsiveness to renal allografts: thymic recognition of immunodominant allo-MHC peptides induces peripheral T cell anergy. Transplantation (Baltimore). 58:125-132.

11. Sayegh, M., N. Perico, O. Imberti, W. Hancock, C. Carpenter, and G. Remuzzi. 1993. Thymic recognition of class II MHC allopeptides induces donor-specific unresponsiveness to renal allografts. Transplantation (Baltimore). 56:461-465.

12. Oluwole, S., M. Jin, N. Chowdhury, and O. Ohajekwe. 1994. Effectiveness of intrathymic inoculation of soluble antigens in the induction of specific unresponsiveness to rat islet allografts without transient recipient immunosuppression. Transplantation (Baltimore). 58:1077-1081.

13. Oluwole, S., N. Chowdhury, M. Jin, and M. Hardy. 1993. Induction of transplantation tolerance in rat cardiac allografts by intrathymic inoculation of allogeneic soluble peptides. Transplantation (Baltimore). 56:1523-1527.

14. Sayegh, M., and A. Krensky. 1996. Novel immunotherapeutic strategies using MHC derived peptides. Kidney Int. 49:S13-S20.

15. Dalloul, A., E. Chmouzis, K. Ngo, and W. Fung-Leung. 1996. Adoptively transferred CD4+ lymphocytes from CD8-/- mice are sufficient to mediate the rejection of MHC class II or class I disparate skin grafts. J. Immunol. 156:4114-4119.

16. Wecker, H., M. Grusby, and H. Auchincloss, Jr. 1995. Effector cells must recognize antigens expressed in the graft to cause efficient skin graft rejection in SCID mice. Transplantation (Baltimore). 59:1223-1227.

17. Lehmann, P.V., D. Matesic, G. Benichou, and P.S. Heeger. 1997. Induction of T helper 2 immunity to an immunodominant allopeptide. Transplantation (Baltimore). 64:292-296.

18. Heeger, P.S., W.E. Smoyer, T. Saad, S. Albert, C.J. Kelly, and E.G. Neilson. 1994. Molecular analysis of the helper T cell response in murine interstitial nephritis. J. Clin. Invest. 94:2084-2092.

19. Haqqi, T., X. Qu, M. Sy, and S. Banerjee. 1995. Restricted expression of $\mathrm{T}$ cell receptor $\mathrm{V}$ beta and lymphokine genes in arthritic joints of a TCR V beta a $(\mathrm{H}-2 \mathrm{q})$ mouse strain-BUB/BnJ-with collagen-induced arthritis. Autoimmunity. 20:163-170.

20. Heeger, P., W. Smoyer, M. Jones, S. Hopfer, and E. Neilson. 1996. Heterogeneous $\mathrm{T}$ cell receptor $\mathrm{V} \beta$ gene repertoire in murine interstitial nephritis. Kidney Int. 49:1222-1230.
21. Ortman, R., D. Holderbaum, X. Qu, S. Banerjee, and T. Haqqi. 1994. $\mathrm{BUB} / \mathrm{BnJ}(\mathrm{H}-2 \mathrm{q})$ is a TCR deletion mutant mouse strain (TCR V beta a, $\mathrm{KJ} 16-)$ that is susceptible to type II collagen-induced arthritis. J. Immunol. 152:4175-4182.

22. Matzinger, P. 1991. The JAM test. A simple assay for DNA fragmentation and cell death. J. Immunol. Methods. 145:185-192.

23. Strom, T., P. Roy-Chaudhury, R. Manfro, X. Zheng, P. Nickerson, and K. Wood. 1996. The Th1/Th2 paradigm and the allograft response. Curr. Opin Immunol. 8:688-693.

24. Larsen, C., E. Elwood, D. Alexander, S. Ritchie, R. Hendrix, C. TuckerBurden, H. Cho, A. Aruffo, D. Hollenbaugh, P. Linsley, et al. 1996. Long-term acceptance of skin and cardiac allografts after blocking CD40 and CD28 pathways. Nature. 381:434-438.

25. Russell, M., W. Hancock, E. Akalin, and A. Wallace. 1996. Chronic cardiac rejection in the LEW to F344 rat model. Blockade of CD28-B7 costimulation by CTLA4Ig modulates $\mathrm{T}$ cell and macrophage activation and attenuates arteriosclerosis. J. Clin. Invest. 97:833-838.

26. Orosz, C.G., E. Wakely, S.D. Bergese, A.M. VanBuskirk, R.M. Ferguson, D. Mullet, G. Apseloff, and N. Gerber. 1996. Prevention of murine cardiac allograft rejection with gallium nitrate. Comparison with anti-CD4 monoclonal antibody. Transplantation (Baltimore). 61:783-791.

27. Risch, K., U. Heemann, E. Graser, B. Nebe, H. Nizze, J. Lacha, J. Brock, H. Volk, and M. Lehmann. 1996. Assessment of chronic rejection in permanent accepted renal allografts in anti-CD4 treated rats. Clin. Nephrol. 45: 358-360.

28. Chen, W., B. Murphy, A. Waaga, T. Willett, M. Russell, S. Khoury, and M. Sayegh. 1996. Mechanisms of indirect allorecognition in graft rejection. Class II MHC allopeptide-specific T cell clones transfer delayed-type hypersensitivity in vivo. Transplantation (Baltimore). 62:705-710.

29. Halloran, P., A. Wadgymar, and P. Autenfried. 1986. The regulation of expression of major histocompatibility complex products. Transplantation (Baltimore). 41:413-420.

30. Kondo, T., A. Novick, H. Toma, and R. Fairchild. 1996. Induction of chemokine gene expression during allogeneic skin graft rejection. Transplantation (Baltimore). 61:1750-1757.

31. Border, W., and N. Noble. 1994. Transforming growth factor- $\beta$ in tissue fibrosis. N. Engl. J. Med. 331:1286-1292.

32. Agarwal, A., Y. Kin, A. Matas, J. Alam, and K. Nath. 1996. Gas-generating systems in acute renal allograft rejection in the rat. Coinduction of heme oxygenase and nitric oxide synthase. Transplantation (Baltimore). 61:93-98. 